\title{
Regeneration and Early Tending of Black Locust (Robinia pseudoacacia L.) Stands in the North- West of Romania
}

\author{
Valeriu-Norocel Nicolescu ${ }^{1}$, Cornelia Buzatu-Goanță2*, Debbie Bartlett ${ }^{3}$, Nicolae lacobb
}

(1) Transilvania University of Brasov, Faculty of Silviculture and Forest Engineering, Șirul Beethoven 1, RO-500432 Brasov, Romania; (2) Banat's University of Agricultural Sciences and Veterinary Medicine "King Michael I of Romania", Faculty of Horticulture and Forestry, Calea Aradului 119, RO-300645 Timișoara, Romania; (3) University of Greenwich, Faculty of Engineering and Science, University of Greenwich, Kent ME4 4TB, United Kingdom; (4) National Forest Administration-ROMSILVA, Săcueni Forest District, Bihor County Branch, RO-417435 Săcueni, Romania

* Correspondence: e-mail: corneliahernea@yahoo.com
Citation: NICOLESCU V-N, BUZATUGOANȚĂ C, BARTLETT D, IACOB N 2019 Regeneration and Early Tending of Black Locust (Robinia pseudoacacia L.) Stands in the North-West of Romania. South-east Eur for 10 (2): 97-105. DOI: https://doi. org/10.15177/seefor.19-14

Received: 19 Jun 2019; Revised: 8 Jul 2019; Accepted: 8 Jul 2019; Published online: 13 Aug 2019

\begin{abstract}
Background and Purpose: The aim of this study is to highlight the importance of black locust (Robinia pseudoacacia L.), a North American-originating tree species of major importance in Romania, in extreme site conditions such as sand dunes. In this respect, a Research and Development (R\&D) project has been carried out in Carei-Valea lui Mihai Plain (north-west of Romania) since 2016.

Materials and Methods: Three sub-compartments were selected in IV Valea lui Mihai Working Circle, Săcueni Forest District: two pure natural regenerations by root suckers of black locust at different ages (sub-compartments 3B and 52A\%) and a mixed black locust - black cherry stand (sub-compartment 23D). Biometrical measurements and analyses as well as biomass estimations were performed. A thorough statistical analysis using the data on initial, extracted and residual trees/ stands was also performed.

Results: The main outputs of the project are as follows: (1) Black locust was established naturally by root suckers and the stocking of newly established stands can be as high as 50,000 suckers $\cdot h^{-1} ;$; $(2)$ The initial growth of black locust regeneration is quick and the young regeneration can close the canopy in 1-2 years, resulting in an appropriate dune fixation and wind erosion control; (3) The young pure or mixed black locust-dominated stands are left untended until the first cleaningrespacing (mean diameter 5-6 cm), when the stand shows high stocking/density and a wide variation in tree size. This intervention is from below, heavy (intensity over $25 \%$ by number of trees or basal area) and of negative selection type, removing mostly low Kraft's class, dead or dying, and defective trees.

Conclusions: This R\&D project has shown the high potential of black locust to establish naturally by root suckers after a low coppice cut and stump removal, as well as the fast initial growth of regenerated black locust. The quick canopy closure of young regeneration results in an appropriate dune fixation and wind erosion control.
\end{abstract}

Keywords: black locust, natural regeneration, release cutting, cleaning-respacing, initial growth

\section{INTRODUCTION}

\section{Black Locust in the World, in Europe and in Romania}

Black locust (Robinia pseudoacacia L.) originates from the eastern part of the United States, where it is found in two areas, in the eastern (Pennsylvania, Ohio, Alabama, Georgia and South Carolina) and western area (Missouri, Arkansas, and Oklahoma) [1].
Globally, black locust was introduced and became naturalized in all sub-Mediterranean and temperate regions: Asia (i.e. South Korea - over 1.2 million ha; China - over 1 million ha; India, Pakistan, Japan), Australia, New Zealand, Africa (North and South), South America (Argentina, Chile) [2-7]. Black locust is now rivaling poplar as the second most planted broadleaved tree species in the world, after the eucalypts [8-10]. This expansion worldwide is due to the fact 
that black locust is an economically important multipurpose tree, in wood production (e.g. firewood, pulpwood, flooring, railway sleepers, boat building, fences, construction, barrel staves, veneer, solid furniture), fodder production, honey production, as a source of bio-oil, for biomass production and carbon sequestration, soil stabilization, erosion control, re-vegetation of landfills, mining areas and wastelands, in biotherapy, and landscape architecture [11-22].

Black locust was the first North American forest tree species to be imported to Europe at the beginning of the $17^{\text {th }}$ century $(1601)[12,18,23,24]$. Currently, black locust is naturalized in thirty-two European countries (Pyšek et al. 2009 , in [21]), covering a total area of 2,306,607 ha [25], and it is the most used non-native broadleaved tree species on the continent.

In Romania, black locust was introduced as a park tree around 1750, probably from Turkey, in the southern and eastern provinces (Wallachia and Moldova), as well as through Serbia and Austro-Hungary in Transylvania (centre) and Banat (south-west) provinces [26]. The first forest plantation including black locust was established in the south-west of Romania (Oltenia Plain) in 1852, in order to stabilize mobile sand dunes [26, 27]. After 1883, it was widely introduced throughout the country for the same purpose as sand dune systems extend to about 266,000 ha in Romania (about $1 \%$ of the national territory [28, 29]).

The area covered by black locust in 1922 was only 28,000 ha [30], expanding to ca. 100,000 ha by the mid1950s [12] and further to approx. 250,000 ha at the present time ( $4 \%$ of national forest land, mostly in the south of the country, on sand dunes and areas with heavy soils in the forest steppe zone) [20,31].

\section{Regeneration and Early Growth of Black Locust}

In different parts of the world, black locust is regenerated by one of three methods:

a) Planting in spring using 1-year-old seedlings, normally bare-rooted, 0.5-1.0 (or even 2) m tall, produced in conventional nurseries [3, $32,33]$. The initial stocking rate of black locust plantations in Europe is very variable: $1,100-1,900$ seedlings'ha ${ }^{-1}$ in France (Bourgogne) [34], 1,2001,700 seedlings ha $^{-1}(4 \times 2 \mathrm{~m}$, or $3 \times 2 \mathrm{~m})$ in France (Aquitaine and Poitou-Charentes) [35], 2,000-2,500 seedlings $\cdot \mathrm{ha}^{-1}(2.5 \times 2.0 \mathrm{~m}$, or $2.5 \times 1.6 \mathrm{~m})$ in Poland [10] to $4,000-5,000$ seedlings ha $^{-1}(2.0 \times 1.25 \mathrm{~m}$, or $2.0 \times 1.0 \mathrm{~m}$ in Romania; $2.4 \times 0.7-0.8 \mathrm{~m}$, or $2.4 \times 1.0 \mathrm{~m}$ in Hungary) [33, 36-38].

b) Naturally by seed. This is rare, as the hard and impermeable seed coat limits germination in the forest/natural environment. However, there are some examples of natural regeneration in the literature $[12,15]$, this process being facilitated by seed wounding with heavy machinery, or natural thermal shock [24].

c) Naturally by vegetative regeneration from stool shoots and root suckers. As black locust coppices freely this is considered the most cost-effective management system for the species [21, 23]. The method is cheap, efficient and allows local people to collect stem wood, which is highly valued as firewood. Root suckers live longer and are healthier (i.e. show less rot at the same age) than stool shoots; however, the latter grow quicker up to 1215 years of age than root suckers $[12,13]$. The most common rejuvenation method is by root suckers since black locust develops horizontal, shallow and wide-spreading roots which can extend 15-20 m from the parent tree $[3,12,15]$.

\section{Early Management of Black Locust Stands}

The application of early management operations such as release cutting and cleaning-respacing in black locust stands varies according to the regeneration method as follows:

a) In plantations with up to 5,000 seedlings $\cdot$ ha $^{-1}$ there is no need for any release cutting $[10,18,40]$. In such stands cleaning-respacing begins after canopy closure, at 4-5 years. and the stocking should be reduced to about 2,500 trees $\cdot \mathrm{ha}^{-1}[10]$. The second cleaning follows 2-3 years later, with a further reduction to ca. 1,700 trees $\cdot$ ha $^{-1}[10]$.

b) In black locust coppice stands regenerated from stool shoots and root suckers, release cutting is necessary to reduce the number of shoots per stool to 1 or 2 and to protect root suckers from stool shoot competition [13, 39]. Normally two release cuttings are performed, the first one in the first or second year, followed by another 1-3 years subsequently [40, 41]. In Romania, two cleaningrespacing operations are performed in years 3-4 and 6-7, reducing the canopy cover to $80-85 \%$.

In both black locust plantations and coppice stands cleaning-respacing is considered to be "the basis for all good management in black locust stands" [42]. These authors aimed to heavily reduce the number of stems, allowing the potential final crop trees sufficient space to grow. If this intervention is too late or too light, the remaining trees do not develop their crowns normally (they are deformed or very small) as this is a strong light-demanding species and is intolerant of shade/competition $[12,14,16]$. The cleaningrespacing is based on negative selections (particularly in the first intervention) removing defective trees, for example, those that are forked (this species is sensitive to early frosts, leading to forking $[13,43])$, badly formed, wounded, bentover (the effect of strong phototropism), combined with positive selections where even well-formed and healthy individuals are removed to provide additional growing space to those selected to remain [43]. Halupa and Rédei [42] highlighted the importance of cleaning-respacing to produce regular spacing of the remaining trees.

In the context of these characteristics of black locust stands and silviculture in the early stages, a Research and Development (R\&D) project was launched in 2016, in order to evaluate the regeneration and early tending of black locust stands in the north-west of Romania. The objectives of this project are (1) to assess the regeneration potential of black locust by root suckers, (2) to assess the early growth of root sucker stems, and (3) to follow and evaluate the early results of these interventions in terms of quality, growth and yield of young black locust stands. 


\section{MATERIALS AND METHODS}

\section{Study Sites}

In order to achieve the objectives set out above, fieldwork was undertaken in black locust stands managed by the Săcueni Forest District, part of Bihor County Branch, National Forest Administration ROMSILVA. These stands are located in the north-west of Romania (Carei-Valea lui Mihai Plain; 46 $58^{\prime} \mathrm{N}, 22^{\circ} 16^{\prime} \mathrm{E}$ ), and comprise three subcompartments which are part of the IV Valea lui Mihai Working Unit.

The study area had the following main characteristics. Landform is continental sand dunes, of river and wind origin, formed in the Holocene, with a SW-NE and NWSE orientation and an elevation between 140 and 160 $m$ [44]. According to Spîrchez et al. [44] and Târziu and Spârchez [45], the local soils are part of the Psamments suborder, Entisols order (sandy soils), with the following characteristics: (i) very deep but poor, with low fertility and low nutrient (N, P, and K) content; (ii) light soil texture (85$90 \%$ sand, mostly fine); (iii) moderately acid to neutral (5 to 7) $\mathrm{pH}$; (iv) maximum fraction of humus is $1 \%$ in the upper 25 $\mathrm{cm}$ of soil; ( $\mathrm{v}$ ) presence of a hard and poorly drained ortstein (ironpan) horizon, $\mathrm{Al}, \mathrm{Fe}, \mathrm{Mn}$, and humus compounds-rich from the overlying shallow $O$ horizon [44]. This horizon restricts water infiltration during the driest summer periods, when the sand gets very warm at the surface, and provides, to a considerable depth, important water supply for the forest vegetation.

The local climate is classified as temperate-continental, compared to a humid climate in the native range of black locust [1]. Mean annual temperature: 10.3ㄷ; maximum monthly temperatures in July: 20.7 우 minimum in January: -1.6 ․ C. Mean annual total precipitation: $573.3 \mathrm{~mm}$. The maximum monthly precipitation is in June is $83 \mathrm{~mm}$, and the minimum in March is $30 \mathrm{~mm}$.

Potential mean annual total evapo-transpiration is around $600 \mathrm{~mm}$, similar to the mean annual total precipitation. Maximum wind speed is $4.0 \mathrm{~m} \cdot \mathrm{s}^{-1}$ (South), so no wind damage to forest vegetation normally occurs (the black locust stands have deep vertical roots to depths of 2-3 $\mathrm{m}$ or more [44]). The only exception was the event on August 3, 1988, when the wind speed reached $18 \mathrm{~m} / \mathrm{s}$ and the volume of damaged black locust reached 1,087 $\mathrm{m}^{3}$ (3,599 trees) [46]. Mean length of frost-free period is 270 days, much longer than in the native range, where it is between 150 and 210 days [1]. The mean annual aridity (de Martonne) index is 28.2 , so the area is considered to be located in the transition zone between the plain forest zone, moderately humid, and the forest steppe zone.

\section{Forest Vegetation}

The first black locust plantations (200 ha, $2 \times 2 \mathrm{~m}$ initial spacing) on sandy soils in the Carei-Valea lui Mihai Plain were established in 1892 [44, 47]. Until 1933 only smallscale plantations including Scots pine (Pinus sylvestris L.), black pine (Pinus nigra Arn.), pedunculate oak (Quercus robur L.), northern red oak (Q. rubra L.), pin oak (Q. palustris Muenchh.), and black cherry (Prunus serotina Ehrh.) were established on about 18 ha. Further plantations were established between 1933 and 1940 (792 ha), 1946-1959 (1,958 ha), and 1960-1980 (450 ha), with the majority being situated on low-fertility former agricultural land [44]. Currently forest vegetation covers about $12 \%$ of the total area of the Carei-Valea lui Mihai Plain, with black locust being the main tree species covering over $80 \%$ of the total forest area (ca. 3,000 ha).

In the Carei-Valea lui Mihai Plain, black locust has been used since 1892 on (i) low-fertility former agricultural land, or (ii) for replacing low-productive tree species such as Quercus robur L., Tilia cordata Mill., Acer campestre L., and Ulmus minor Mill., in order to prevent wind erosion and sand dune movement and to produce firewood. Subsequently, black locust stands were treated as simple coppice, usually on a rotation of 20-30 years, but up to 35 years, similar to the time scales found in the USA [14], India [3], France [34, $35]$ and Hungary $[38,48]$.

\section{Experimental Material}

In this context, three sub-compartments (scpt.) - 3B, $23 D$ and $52 A \%$ - were selected for the R\&D project. The main characteristics of these stands are: (1) Scpt. 3B pure natural regeneration by root suckers of black locust, 1-year old, following simple coppice cut (winter 2015-2016) and the removal of stumps; (2) Scpt. 52A\% - pure natural regeneration by root suckers of black locust, 2-years old, following simple coppice cut (winter 2013-2014) and the removal of stumps; (3) Scpt. 23D - mixed black locust-black cherry stand, 12-years old, originating from root suckers after a simple coppice cut (2004) and the removal of stumps. No silvicultural interventions had been performed since the establishment.

\section{Experimental Design}

In order to carry out the fieldwork, different experimental plots were designed: (1) Scpt. 3B - six plots of $25 \mathrm{~m}^{2}$ (5×5 m) each, established in April 2017 (Figure 1); (2) Scpt. 52A\% - two plots of $25 \mathrm{~m}^{2}(5 \times 5 \mathrm{~m})$ each, established in June 2016; (3) Scpt. 23D - two plots of $150 \mathrm{~m}^{2}(15 \times 10 \mathrm{~m})$, established in July 2016.

\section{Root Suckers/Tree Measurements}

Root collar diameter and total height were measured for all initial and remaining root suckers, after the release cutting carried out in all plots from scpts. $3 B$ and $52 \mathrm{~A} \%$. Diameter at breast height (DBH) and total height for all initial and remaining trees after cleaning-respacing were measured in scpt. 23D. The location $(x-y)$ of each remaining tree as well as four perpendicular crown radii for such trees was also measured.

\section{Biomass Estimation}

The suckers cut during the release intervention (scpt. 3B) were bundled in each plot and transported to the laboratory. The dry matter content was determined by drying material at $105 \circ \mathrm{C}$, until constant weight was reached. To assess biomass production, an allometric relationship between $\mathrm{W}$ and stem diameter was used according to: $\mathrm{W}=\mathrm{bD}^{\mathrm{c}}$, where $\mathrm{W}$ - biomass, $\mathrm{D}$ - root collar diameter, $\mathrm{b}$ and c-constant parameters. 
Silvicultural, Biometrical and Statistical Analysis

Using the data collected in the field the following calculations were performed: stocking (no. of trees.ha-1) before and after release cutting and cleaning-respacing, in order to determine the intensity of the interventions; density $\left(\mathrm{m}^{2} \cdot \mathrm{ha}^{-1}\right)$ before and after cleaning-respacing, with the same purpose; mean collar diameter in release cutting, DBH in cleaning-respacing of the initial, extracted and remaining trees and their standard deviations; mean height (in both release cutting and cleaning-respacing) of the initial, extracted and remaining trees and their standard deviations; dry biomass of extracted, remaining and initial suckers in scpt. 3B; coefficients of variation of diameters and heights (initial, extracted and remaining suckers or trees); significant differences between means were tested using ANOVA and Duncan post hoc test [49].

\section{RESULTS AND DISCUSSION}

\section{(A) Regeneration of Black Locust Stands}

In the two sub-compartments analyzed with respect to natural regeneration of black locust by root suckers, the most relevant results are as follows:

(i) 1-year old natural regeneration (scpt. 3B)

The potential for natural regeneration of black locust from root suckers was very high and the initial stocking after one growing season ranged between 15,200 and 67,600 suckers $\cdot \mathrm{ha}^{-1}$ (50,800 on average). The initial stocking was higher than the one found in the study conducted in France, which recorded over 40,000 suckers $\cdot \mathrm{ha}^{-1}$ by using this regeneration method (Pagès 1985, cited in [35] - Figure 2).

This very high stocking allowed for very heavy interventions (over $25 \%$ of the number of trees [40]) with release cutting (from $68.42 \%$ to $91.89 \%$, over $80 \%$ in the majority of plots), reducing the stocking per ha to between 4,800 suckers and 9,200 suckers (7,200 suckers on average) (Table 1).

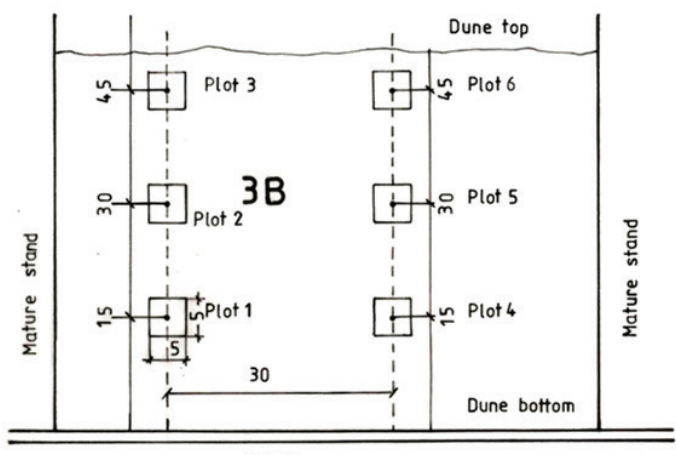

\section{$36 \mathrm{D}$}

FIGURE 1. Location of plots 1-6 within the scpt. 3B.

Significant differences $(F=4.735, p=0.0003)$ were registered in terms of root collar diameter for root suckers located on the dune top, in the middle of the slope and the bottom of the dune at the beginning of the experiment. The same pattern was observed for the removed root suckers ( $F=4.942, p=0.0002$ ).

The suckers removed by release cutting were the smallest (or thinnest) ones. Consequently, the arithmetic mean collar diameter of black locust suckers increased from $7.36 \pm 3.91-9.81 \pm 5.32 \mathrm{~mm}$ to $11.67 \pm 4.12-14.72 \pm 6.76 \mathrm{~mm}$, the coefficients of variation of diameters being the lowest in the remaining root suckers. No significant differences were registered for the remaining root suckers ( $F=1.010$, $\mathrm{p}=0.416$ ) (Table 2).

The suckers extracted through this intervention were also the shortest, so the arithmetic mean height of black locust suckers increased from $87.79 \pm 40.18-100.18 \pm 63.29$ $\mathrm{cm}$ to between $126.33 \pm 35.06$ and $175.67 \pm 44.88 \mathrm{~cm}$, the coefficients of variation of heights being also the smallest in the remaining root suckers. In terms of root sucker height,

TABLE 1. Stocking in the six plots located in the 1-year old regeneration and the intensity of release cutting.

\begin{tabular}{|c|c|c|c|c|c|c|c|}
\hline \multirow{3}{*}{ Plot no. } & \multicolumn{6}{|c|}{ Number of root suckers per plot/ha } & \multirow{3}{*}{$\begin{array}{c}\text { Intensity of } \\
\text { intervention \% }\end{array}$} \\
\hline & \multicolumn{2}{|c|}{ Initial } & \multicolumn{2}{|c|}{ Extracted } & \multicolumn{2}{|c|}{ Remaining } & \\
\hline & plot & ha & Plot & ha & plot & ha & \\
\hline 1 & 156 & 62,400 & 135 & 54,000 & 21 & 8,400 & 86.54 \\
\hline 2 & 148 & 59,200 & 136 & 54,400 & 12 & 4,800 & 91.89 \\
\hline 3 & 119 & 47,600 & 101 & 40,400 & 18 & 7,200 & 84.87 \\
\hline 4 & 38 & 15,200 & 26 & 10,400 & 12 & 4,800 & 68.42 \\
\hline 5 & 169 & 67,600 & 146 & 58,400 & 23 & 9,200 & 86.39 \\
\hline 6 & 130 & 52,000 & 109 & 43,600 & 21 & 8,400 & 83.85 \\
\hline Average no. & 127 & 50,800 & 109 & 43,600 & 18 & 7,200 & 85.83 \\
\hline Range & & $15,200-67,600$ & & $10,400-58,400$ & & $4,800-9,200$ & \\
\hline
\end{tabular}


TABLE 2. Arithmetic mean collar diameters (mean), arithmetic mean height (mean), standard deviations (SD) and coefficients of variation (CV) of black locust root suckers (initial, extracted, and remaining) in the 1-year old regeneration.

\begin{tabular}{|c|c|c|c|c|c|c|c|c|c|c|c|c|}
\hline \multirow{2}{*}{$\begin{array}{l}\text { Plot } \\
\text { no. }\end{array}$} & \multicolumn{4}{|c|}{ Initial root suckers } & \multicolumn{4}{|c|}{ Extracted root suckers } & \multicolumn{4}{|c|}{ Remaining root suckers } \\
\hline & Mean & \pm & SD & CV & Mean & \pm & SD & CV & Mean & \pm & SD & CV \\
\hline \multicolumn{13}{|c|}{ Collar diameter $(\mathrm{mm})$} \\
\hline 1 & $7.36^{\mathrm{b}}$ & \pm & 3.91 & 53.15 & $6.58^{b}$ & \pm & 3.35 & 50.92 & 12.38 & \pm & 3.57 & 28.84 \\
\hline 2 & $7.87^{\mathrm{b}}$ & \pm & 4.84 & 61.44 & $7.30^{\mathrm{b}}$ & \pm & 4.38 & 60.04 & 14.33 & \pm & 5.21 & 36.35 \\
\hline 3 & $9.81^{\mathrm{a}}$ & \pm & 5.32 & 54.22 & $8.93^{\mathrm{a}}$ & \pm & 4.53 & 50.66 & 14.72 & \pm & 6,76 & 45.94 \\
\hline 4 & $7.71^{\mathrm{b}}$ & \pm & 4.01 & 52.02 & $5.89^{b}$ & \pm & 2.32 & 39.40 & 11.67 & \pm & 4.12 & 35.31 \\
\hline 5 & $7.71^{\mathrm{b}}$ & \pm & 4.45 & 57.65 & $7.04^{b}$ & \pm & 3.98 & 56.57 & 11.96 & \pm & 4.95 & 41.40 \\
\hline 6 & $8.90^{\mathrm{ab}}$ & \pm & 5.85 & 65.76 & $8.07^{\mathrm{ab}}$ & \pm & 5.61 & 69.56 & 13.24 & \pm & 5.24 & 39.61 \\
\hline All plots & 8.20 & \pm & 4.87 & 59.43 & 7.42 & \pm & 4.37 & 58.88 & 12.99 & \pm & 5.08 & 39.12 \\
\hline \multicolumn{13}{|c|}{ Height $(\mathrm{cm})$} \\
\hline 1 & 89.08 & \pm & 47.64 & 53.48 & 78.62 & \pm & 40.67 & 51.73 & 156.33 & \pm & 31.94 & 20.43 \\
\hline 2 & 91.61 & \pm & 51.15 & 55.83 & 84.20 & \pm & 44.74 & 53.13 & 175.67 & \pm & 44.88 & 25.55 \\
\hline 3 & 95.58 & \pm & 52.88 & 55.32 & 84.91 & \pm & 45.51 & 53.60 & 155.44 & \pm & 52.46 & 33.75 \\
\hline 4 & 87.79 & \pm & 40.18 & 45.77 & 70.00 & \pm & 28.40 & 40.57 & 126.33 & \pm & 35.06 & 27.75 \\
\hline 5 & 96.81 & \pm & 53.91 & 55.68 & 86.66 & \pm & 46.81 & 54.01 & 161.22 & \pm & 52.25 & 32.41 \\
\hline 6 & 100.18 & \pm & 63.29 & 63.18 & 89.19 & \pm & 59.32 & 66.51 & 157.19 & \pm & 52.55 & 33.43 \\
\hline All plots & 100.18 & \pm & 53.14 & 56.45 & 83.98 & \pm & 46.83 & 55.77 & 156.21 & \pm & 46.99 & 30.08 \\
\hline
\end{tabular}

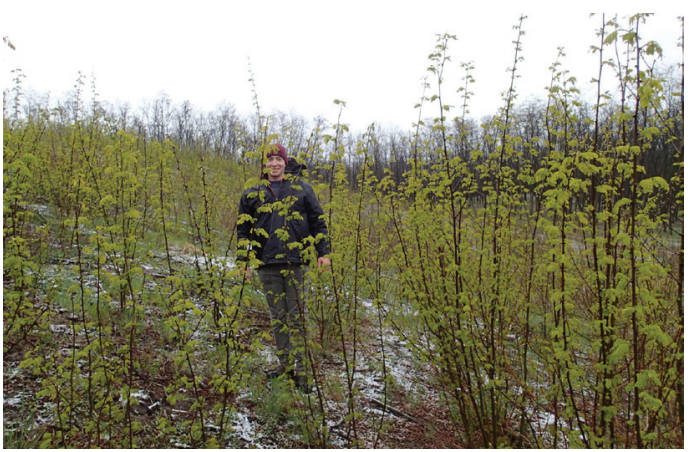

a)

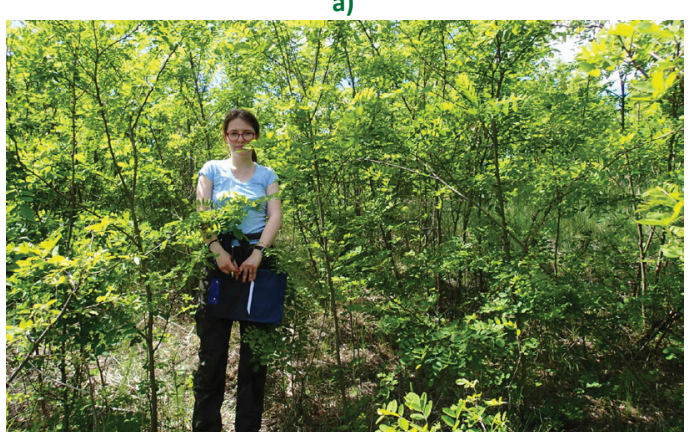

b)

FIGURE 2. Aspect of young regeneration by root suckers in:

(a) 20 April 20 2017, and (b) 18 May 2019.

(Photos V.N. Nicolescu). the analysis of variance showed no significant differences: $F=0.896, p=0.483$ for initial root suckers, $F=1.193, p=0.311$ for removed root suckers and $F=1.469, p=0.207$ for the remaining ones.

The aboveground dry biomass of initial, extracted, and remaining black locust root suckers in the six plots was calculated using the allometric formula $W=0.652 D^{2.582}$, $\mathrm{R}^{2}=0.9426$.

The initial aboveground dry biomass in all plots, except plot no. 4, exceeded $1.1 \mathrm{t} \cdot \mathrm{ha}^{-1}$ (1.384 th ha ${ }^{-1}$ on average), the maximum being measured in plots $3\left(1.875 \mathrm{t} \cdot \mathrm{ha}^{-1}\right)$ and 6 (1.939 t.ha-1) (Table 3), which were both located close to the dune top.

As the release cutting intervention had very heavy intensity, the remaining aboveground biomass was less than $0.5 \mathrm{t} \cdot \mathrm{ha}^{-1}$, with the exception of plots $3\left(0.699 \mathrm{t} \cdot \mathrm{ha}^{-1}\right)$ and $6\left(0.565 \mathrm{t} \cdot \mathrm{ha}^{-1}\right)$, with a mean of $0.462 \mathrm{t} \cdot \mathrm{ha} \mathrm{a}^{-1}$.

(ii) 2-years old natural regeneration (scpt. 52A\%)

This stand was regenerated identically to scpt. 3B and is located in very similar ecological conditions. In the two plots very strong competition between the suckers started immediately after the canopy closure of the newly established regeneration, i.e. at the end of the first growing season, producing an abrupt reduction in stocking of this 2-years old stand (12,000 suckers.ha-1 in plot 1 and 22,000 suckers $\cdot$ ha $^{-1}$ in plot 2) (Table 4).

The mean collar diameters $(6.9 \mathrm{~mm}$ and $6.7 \mathrm{~mm}$ respectively) and mean height $(162 \mathrm{~cm}$ and $155 \mathrm{~cm}$ respectively) are similar in the two plots. The ranges in both of these parameters are similar and no significant 
TABLE 3. Dry biomass of root suckers in the 1-year old regeneration.

\begin{tabular}{cccc}
\hline \multirow{2}{*}{$\begin{array}{c}\text { Plot } \\
\text { no. }\end{array}$} & \multicolumn{3}{c}{ Dry biomass $\left(\mathrm{t} \cdot \mathrm{ha}^{-1}\right)$} \\
\cline { 2 - 4 } & Extracted & Remaining & Initial \\
\hline 1 & 0.721 & 0.422 & 1.143 \\
2 & 1.129 & 0.379 & 1.508 \\
3 & 1.176 & 0.699 & 1.875 \\
4 & 0.087 & 0.219 & 0.306 \\
5 & 1.044 & 0.488 & 1.532 \\
6 & 1.374 & 0.565 & 1.939 \\
Mean & 0.922 & 0.462 & 1.384 \\
Range & $0.087-1.374$ & $0.219-0.699$ & $0.306-1.939$ \\
\hline
\end{tabular}

statistical differences occurred $(F=0.132, p=0.717$ for collar diameter and $F=0.372, p=0.543$ for height) between the collar diameter and the height of suckers in these two plots (Table 4).

\section{(B) Cleaning-respacing of young mixed black locust- dominated stands}

This intervention was carried out in scpt. 23D, which showed the following main characteristics:

The stand initial stocking was very high $\left(5,467\right.$ trees $\cdot$ ha $\left.^{-1}\right)$ in plot 1 , and lower $\left(3,533\right.$ trees $\left.\cdot \mathrm{ha}^{-1}\right)$ in plot 2 . These trees had a similar basal area $\left(14.30 \mathrm{~m}^{2} \cdot \mathrm{ha}^{-1}\right.$ in plot 1 and 13.87 $\mathrm{m}^{2} \cdot \mathrm{ha}^{-1}$ in plot 2 ). This made a very heavy intervention possible, with the removal of over $25 \%$ trees, reducing the stocking to 2,333 trees $\cdot \mathrm{ha}^{-1}$ and the basal area to 9.33 $\mathrm{m}^{2} \cdot \mathrm{ha}^{-1}$ (plot 1) and 1,733 trees $\cdot \mathrm{ha}^{-1}$ and $9.10 \mathrm{~m}^{2} \cdot \mathrm{ha}^{-1}$ (plot 2) (Figure 3 and Table 5).

The remaining stocking in the two plots is similar to the one recommended in Hungary (1,800 trees.ha-1 ${ }^{-1}$ [48]) and
TABLE 4. Main characteristics of plots 1 and 2 in the 2 -years old regeneration.

\begin{tabular}{ccccc}
\hline & Plot 1 & Plot 2 & Overall \\
\hline Number of individuals ha-1 & 12,000 & 22,000 & 17,000 \\
\hline Basal area $\left(\mathrm{m}^{2} \cdot \mathrm{ha}^{-1}\right)$ & 0.53 & 0.93 & 0.73 \\
\hline & $\begin{array}{l}\text { Arithmetic } \\
\text { mean }\end{array}$ & 6.9 & 6.7 & 6.8 \\
$\begin{array}{c}\text { Collar diameter } \\
(\mathrm{mm})\end{array}$ & $\begin{array}{l}\text { Maximum } \\
\text { Minimum }\end{array}$ & 14.4 & 15.1 & 15.1 \\
\hline $\begin{array}{c}\text { Arithmetic } \\
(\mathrm{cm})\end{array}$ & $\begin{array}{l}\text { mean } \\
\text { Maximum }\end{array}$ & 257 & 2.0 & 2.8 \\
\hline & Minimum & 60 & 50 & 155 \\
\hline
\end{tabular}

Germany $\left(2,350\right.$ trees $\left.\cdot \mathrm{ha}^{-1}[50]\right)$ and marginally lower than the one in Bulgaria (ca. 2,500 trees $\cdot \mathrm{ha}^{-1}$ [51]).

As the intensity by the number of trees (57.3\% in plot 1 , and $50.9 \%$ in plot 2) was much higher than by the basal area (34.1\% in plot 1 and 34.4 in plot 2), the intervention was from below in both plots, removing mostly trees from the lower diameter classes.

As the intervention removed mostly the smallest (thinnest and shortest) trees, the arithmetic mean diameter and arithmetic mean height increased in both black locust and black cherry, particularly in the former species (Table 6).

Even though black locust and black cherry have similar heights $(F=3.781, p=0.054)$, significant differences were found in the case of diameter ( $F=67.051, p=0.000)$.

The intervention produced gaps in the canopy cover, which shows a value after cleaning-respacing of ca. $80 \%$ in plot 1 , and $75 \%$ in plot 2 , so that some trees have additional space at the canopy level to develop their crowns and consequently increase DBH.

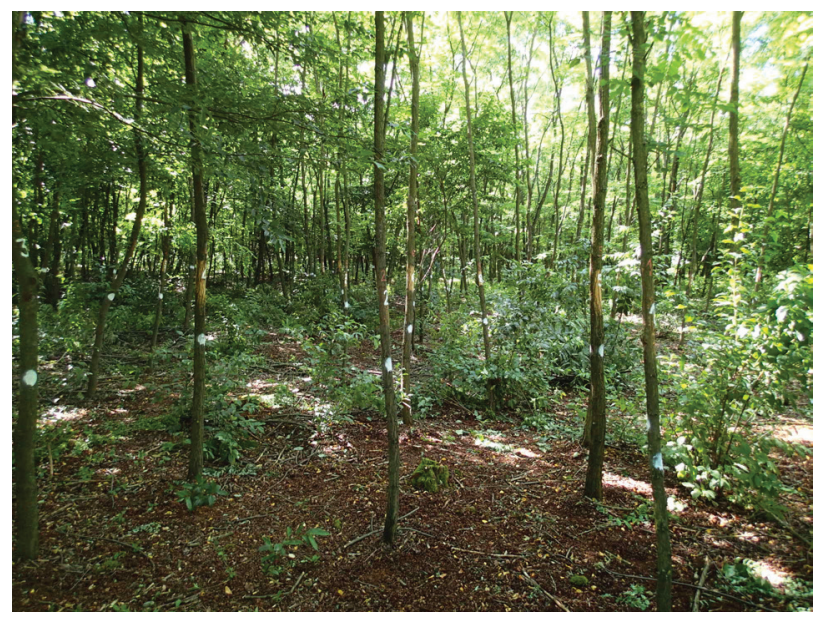

FIGURE 3. Aspect of plot 1 after the intervention. (Photo V.N. Nicolescu) 
TABLE 5. Main characteristics of stand and of cleaning-respacing carried out in the 12 years-old natural regeneration.

\begin{tabular}{|c|c|c|c|c|c|}
\hline & & Black locust BL & Black cherry BC & Overall & Species composition (\%) \\
\hline \multicolumn{6}{|c|}{ Number of trees $\cdot \mathrm{ha}^{-1}$} \\
\hline \multirow{4}{*}{ Plot 1} & Initial & 4,867 & 600 & 5,467 & 89BL11BC \\
\hline & Extracted & 2,933 & 200 & 3,133 & $94 \mathrm{BL} 6 \mathrm{BC}$ \\
\hline & Remaining & 1,933 & 400 & 2,333 & 83BL17BC \\
\hline & Intensity of intervention (\%) & 60.3 & 33.3 & 57.3 & \\
\hline \multirow{4}{*}{ Plot 2} & Initial & 2,400 & 1,133 & 3,533 & 68BL32BC \\
\hline & Extracted & 1,267 & 533 & 1,800 & 70BL30BC \\
\hline & Remaining & 1,133 & 600 & 1,733 & 65BL35BC \\
\hline & Intensity of intervention (\%) & 52.8 & 47.1 & 50.9 & \\
\hline \multicolumn{6}{|c|}{ Basal area $\left(m^{2} \cdot h a^{-1}\right)$} \\
\hline \multirow{4}{*}{ Plot 1} & Initial & 10.87 & 3.43 & 14.30 & 76BL24BC \\
\hline & Extracted & 4.25 & 0.72 & 4.87 & 87BL13BC \\
\hline & Remaining & 6.62 & 2.71 & 9.33 & 71BL29BC \\
\hline & Intensity of intervention (\%) & 39.1 & 21.0 & 34.1 & \\
\hline \multirow{4}{*}{ Plot 2} & Initial & 5.61 & 8.26 & 13.87 & 40BL60BC \\
\hline & Extracted & 1.82 & 2.95 & 4.77 & $38 \mathrm{BL} 62 \mathrm{BC}$ \\
\hline & Remaining & 3.79 & 5.31 & 9.10 & 42BL58BC \\
\hline & Intensity of intervention (\%) & 32.4 & 35.8 & 34.4 & \\
\hline
\end{tabular}

TABLE 6. Biometrical characteristics of 12-years old naturally regenerated black locust and black cherry before and after intervention.

\begin{tabular}{|c|c|c|c|c|c|c|c|}
\hline & & \multicolumn{3}{|c|}{ Black locust } & \multicolumn{3}{|c|}{ Black cherry } \\
\hline \multirow[b]{2}{*}{ Initial } & Plot 1 & 5.3 & \pm & 1.82 & 8.0 & \pm & 3.50 \\
\hline & Plot 2 & 5.4 & \pm & 1.67 & 9.5 & + & 2.88 \\
\hline \multirow{2}{*}{ Extracted } & Plot 1 & 4.0 & \pm & 1.44 & 6.7 & \pm & 1.15 \\
\hline & Plot 2 & 4.4 & \pm & 1.00 & 8.1 & \pm & 2.21 \\
\hline \multirow{2}{*}{ Remaining } & Plot 1 & 6.5 & \pm & 1.44 & 8.5 & \pm & 4.17 \\
\hline & Plot 2 & 6.5 & \pm & 1.52 & 10.7 & \pm & 2.95 \\
\hline \multicolumn{8}{|c|}{ Arithmetic mean height \pm standard deviation $(\mathrm{m})$} \\
\hline \multirow{2}{*}{ Initial } & Plot 1 & 8.6 & \pm & 2.51 & 8.6 & \pm & 3.00 \\
\hline & Plot 2 & 9.5 & \pm & 2.88 & 10.3 & \pm & 1.77 \\
\hline \multirow[b]{2}{*}{ Extracted } & Plot 1 & 7.0 & \pm & 1.99 & 8.1 & \pm & 1.79 \\
\hline & Plot 2 & 7.9 & \pm & 1.62 & 9.5 & \pm & 1.73 \\
\hline \multirow[b]{2}{*}{ Remaining } & Plot 1 & 10.6 & \pm & 1.38 & 8.9 & \pm & 3.60 \\
\hline & Plot 2 & 10.0 & \pm & 1.33 & 11.0 & \pm & 1.58 \\
\hline
\end{tabular}




\section{CONCLUSIONS}

The R\&D project, which began in 2016, focusing on pure and mixed black locust-dominated stands, has led to the following conclusions on regeneration and the early management of such stands:

- The potential of black locust to establish naturally by root suckers after a low coppice cut and stump removal is very high and the stocking of such newly established stands can exceed 50,000 suckers $\cdot \mathrm{ha}^{-1}$.

- Despite the unfavourable conditions in the case study area, the initial growth of regenerated black locust is fast and the newly established stand can close the canopy in 1-2 years, resulting in effective dune stabilization and wind erosion control.

- There are significant biometric differences, for example in collar diameter and height, between the young shoots, leading to a high level of natural mortality after canopy closure.
- Economic factors, such as lack of markets and/ or workforce, result in young pure or mixed black locust-dominated stands usually being untended in the early stages. The first commercial intervention (cleaning-respacing) occurs when the stand has reached the thicket stage (minimum mean diameter 5-6 cm) and exhibits high stocking and density as well as wide dimensional (diameter and height) variation. Consequently, the first cleaningrespacing intervention is from below, of high intensity and negative selection type, removing mostly low Kraft's class (intermediate/suppressed), dead or dying, and defective (for example forked, wounded, or bent-over) trees.

However, these are only preliminary results and during the next intervention different measurements (e.g. collar diameters and heights - stands for release cutting; diameters, heights and crown radii - stands for cleaningrespacing) will be taken. These will provide an assessment of natural dieback in young, naturally regenerated black locust stands, and the effects of the two silvicultural interventions on the early growth of this species in pure or mixed stands.

\section{REFERENCES}

1. HUNTLEY JC 1990 Robinia pseudoacacia L. Black locust. In: Burns RM, Honkala BH (techn. coord.) Silvics of North America, Volume 2 Hardwoods. Agriculture Handbook 654, Forest Service, United States Department of Agriculture, Washington, DC, USA, pp 755-761

2. 2. KERESZTESI B 1988 Natural range of black locust and its distribution in other countries. In: Keresztesi B (ed) The black locust. Akadémiai Kiadó, Budapest, Hungary, pp 9-17

3. 3. LUNA RK 1996 Robinia pseudoacacia Linn. In: Plantation trees. International Book Distributions, Dehra Dun, India, pp 633-639

4. 4. DEMENE JM, MERZEAU D 2007 Black locust. History and biological characteristics (in French). Forêt-entreprise 177: 1012

5. 5. ȘOFLETEA N, CURTU L 2007 Dendrology (in Romanian). Editura Universității „Transilvania”, Brașov, Romania, 418 p

6. 6. TU B, GAVALAND A, DU K, LU X 2007 Black locust in China (in French). Forêt-entreprise 177: 50-53

7. 7. CIERJACKS A, KOWARIK I, JOSHI J, HEMPEL S, RISTOW M, VON DER LIPPE M, WEBER E 2013 Biological Flora of the British Isles: Robinia pseudoacacia. J Ecol 101 (6): 1623-1640. DOI: https:// doi.org/10.1111/1365-2745.12162

8. 8. SAVILL P 2013 The silviculture of trees used in British forestry. $2^{\text {nd }}$ edition. $C A B$ International, Wallingford, UK, and Boston, USA, $280 p$

9. 9. RÉDEI K 2013 The black locust (Robinia pseudoacacia L.) and its features. In: Rédei, K (ed) Black locust (Robinia pseudoacacia L.) growing in Hungary. Hungarian Forest Research Institute, Sárvár, Hungary, pp 7-11

10. 10. WOJDA T, KLISZ M, JASTRZĘBOWSKI S, MIONSKOWSKI M, SZYP-BOROWKA I, SZCZYGIEt K 2015 The geographical distribution of the black locust (Robinia pseudoacacia L.) in Poland and its role in non-forest land. Papers on Global Change-IGBP 22: 101-113. DOI: https://doi.org/10.1515/igbp2015-0018
11. POSKIN A 1926 Handbook of Silviculture (in French). Jules Duculot, Gembloux, Librairie Agricole de la Maison Rustique, Paris, France, $439 p$

12. NEGULESCU E, SĂVULESCU AL 1957 Dendrology (in Romanian). Editura Agro-Silvică de Stat, Bucharest, Romania, 457 p

13. HARALAMB AT 1967 Culture of tree species (in Romanian). Editura Agro-silvică, Bucharest, Romania, 755 p

14. MCALISTER RH 1971 Black locust (Robinia pseudoacacia L.). U.S. Department of Agriculture. Forest Service, American Woods-FS-24, Washington, D.C., USA, $6 \mathrm{p}$

15. STĂNESCU V 1979 Dendrology (in Romanian). Editura Didactică și Pedagogică, Bucharest, Romania, $470 \mathrm{p}$

16. HARLOW WM, HARRAR ES, WHITE FM 1986 Textbook of dendrology. $6^{\text {th }}$ edition. McGraw-Hill Book Company, New YorkSydney-Tokyo-Toronto, $510 \mathrm{p}$

17. GILMAN EF, WATSON DG 1994 Robinia pseudoacacia Black locust. Fact Sheet ST-570. Environmental Horticulture Department, Florida Cooperative Extension Service, Institute of Food and Agricultural Sciences, University of Florida, Gainesville, Florida, USA, $4 \mathrm{p}$

18. CRPF 2007 The black locust (in French). Centre Régional de la Propriété Forestière de Poitou-Charentes, Smarves, France, $4 \mathrm{p}$

19. DINI-PAPANASTASI O, KOSTOPOULOU P, RADOGLOU K 2012 Effects of seed origin, growing medium and mini-plug density on early growth and quality of black locust (Robinia pseudoacacia L.) seedlings. J For Sci 58 (1): 8-20

20. ENESCU CM, DĂNESCU A 2013 Black locust (Robinia pseudoacacia L.) - an invasive neophyte in the conventional land reclamation flora in Romania. Bulletin of the Transilvania University of Brașov, Series II: Forestry • Wood Industry • Agricultural Food Engineering 6 (55): 23-30

21. SITZIA T, CIERJACKS A, DE RIGO D, CAUDULLO G 2016 Robinia pseudoacacia in Europe: distribution, habitat, usage and threats. In: San-Miguel-Ayanz J, de Rigo D, Caudullo G, Houston Durrant T, Mauri A (eds) A European Atlas of Forest Tree Species. Publications Office of the European Union, Luxembourg, pp 166-167 
22. PEDROL N, PUIG CG, LÓPEZ-NOGEUEIRA A, PARDO-MURAS M, GONZÁLES L, SOUZA-ALONSO P 2017 Optimal and synchronized germination of Robinia pseudoacacia, Acacia dealbata and other woody Fabaceae using a handheld rotary tool: concomitant reduction of physical and physiological seed dormancy. J For Res 29 (2): 283-290. DOI: https://doi. org/10.1007/s1167

23. BîRLĂNESCU E, BELU C 1968 Culture of black locust, focusing on black locust culture in Oltenia. In: Bakoș V (ed) Culture of fast growing tree species (in Romanian). Editura agrosilvică, Bucharest, Romania, pp 332-346

24. STĂNESCU V, ȘOFLETEA N, POPESCU O 1997 Wooden forest flora of Romania (in Romanian). Editura Ceres, Bucharest, Romania $451 \mathrm{p}$

25. BRUS R 2016 Current occurrence of non-native tree species in European forest. Presentation to the Joint WG Meeting of COST Action Non-native tree species for European forests - experiences, risks and opportunities (NNEXT), Lisbon, Portugal, $4^{\text {th }}$ of October 2016

26. DRĂCEA MD 1919 When and on what pathway the black locust came to us? (in Romanian). Economia forestieră 3-4: 71-75

27. CRĂCIUNESCU G 1904 Afforestation of flying sands from the Piscu-Tunari and Ciuperceni State estates, Doljiu County (in Romanian). Revista pădurilor XVIII(II): 202-210

28. CIORTUZ I, PĂCURAR VD 2004 Land improvement (in Romanian). Editura Lux Libris, Brașov, Romania, $232 \mathrm{p}$

29. TÂRZIU DR 2008 General and forestry soils (in Romanian). Editura Universității „Transilvania”, Brașov, Romania, 272 p

30. DRĂCEA M 1928 Contribution to the knowledge of black locust in Romania, with special emphasis on its culture on sandy soils of Oltenia (in German). Tipografia „Lucia”, Bucharest, Romania $112 \mathrm{p}$

31. NICOLESCU VN, HERNEA C, BAKTI B, KESERÜ Z, ANTAL B, RÉDEI K 2018 Black locust (Robinia pseudoacacia L.) as a multipurpose tree species in Hungary and Romania: a review. J For Res 29 (6) 1449-1463. DOI: https://doi.org/10.1007/s11676018-0626-5

32. OLSON DF 1974 Robinia L. Locust. In: Schopmeyer, CS (techn. coord.) Seeds of woody plants in the United States. Agriculture Handbook No. 450, Forest Service, U.S. Department of Agriculture, Washington, D.C., USA, pp 728-731

33. RÉDEI K 2013 Stand establishment. In: Rédei, K (ed) Black locust (Robinia pseudoacacia L.) growing in Hungary. Hungarian Forest Research Institute, Sárvár, Hungary, pp 2734

34. BORDE B 2011 Black locust in Bourgogne (in French). Centre Régional de la Propriété Forestière de Bourgogne, Chalons sur Saône, France, $19 p$

35. CARBONNIÈRE T., DEBENNE JN, MERZEAU D, RAULT M 2007 Black locust in Aquitaine (in French). Forêt-entreprise 177: 1317
36. MAPPM 2000a Technical norms on species compositions, planting schemes and forest regeneration technologies and afforestation of degraded lands 1 (in Romanian). Ministerul Apelor, Pădurilor și Protecției Mediului, Bucharest, Romania, $272 p$

37. RÉDEI K, OSVATH-BUJTAS Z, VEPERDI I 2008 Black Locust (Robinia pseudoacacia L.) Improvement in Hungary: a Review. Acta Silvatica and Lignaria Hungarica 4: 127-132

38. RÉDEI K, CSIHA I, KESERŰ Z, KAMANDINÉ VÉGH A, GYÖRI J 2011 The Silviculture of Black Locust (Robinia pseudoacacia L.) in Hungary: a Review. South-east Eur for 2 (2): 101-107. DOI: https://doi.org/10.15177/seefor.11-11

39. DEBENNE JN 1988 Black locust, a short rotation species indispensable in the rural areas (in French). Forêts de France 314: 29-31

40. MAPPM 2000 Technical norms on tending operations 2 (in Romanian). Ministerul Apelor, Pădurilor și Protecției Mediului, Bucharest, Romania $163 \mathrm{p}$

41. COSTEA A, LĂZĂRESCU C, BîRLĂNESCU E, IVANSCHI T, ARMĂȘESCU S, TRANTESCU GR, LATIȘ L, PÎRVU E 1969 Recommendations on black locust Robinia pseudacacia L. culture (in Romanian). ICSPS, Bucharest, Romania, $38 \mathrm{p}$

42. HALUPA L, RÉDEI K 1988 Forest tending. In: Keresztesi, B (ed) The black locust. Akadémiai Kiadó, Budapest, Hungary, pp 115-125

43. 43. CONSTANTINESCU N 1976 Tending of forest stands (in Romanian). Vol. II. Editura Ceres, Bucharest, Romania, 402 p

44. SPÂRCHEZ Z, I. RĂSMERIȚĂ I, RIȚIU A 1962 Afforestation of sandy lands from the north-west of the country (in Romanian). Ministerul Agriculturii, Editura Agro-Silvică, Bucharest, Romania, $117 \mathrm{p}$

45. TÂRZIU DR, SPÂRCHEZ GH 2013 Forest soils and sites (in Romanian). Editura Universității Transilvania, Brașov, Romania, $257 \mathrm{p}$

46. RIȚIU A, NICOLESCU L, NICOLESCU N 1988 Some considerations on windfalls and windbreaks in black locust forests in the north-west of the country (in Romanian with English summary). Revista pădurilor 3: 131-133

47. ICAS 2008 Forest management plan of IV Working Circle Valea lui Mihai (in Romanian). Institutul de Cercetări și Amenajări Silvice, Stațiunea Oradea, Romania, $302 \mathrm{p}$

48. RÉDEI K 2013 Tending and yield of black locust stands. In: Rédei, K (ed) Black locust (Robinia pseudoacacia L.) growing in Hungary. Hungarian Forest Research Institute, Sárvár, Hungary, pp 35-46

49. STATSOFT, INC. 2004 STATISTICA (data analysis software system), version 7. www.statsoft.com

50. LOCKOW KW, LOCKOW J 2015 Yield table for black locust (Robinia pseudoacacia L.) (in German). Ed. Gesellschaft zur Förderung schnellwachsender Baumarten, Eutin, Germany, $80 \mathrm{p}$

51. PORYAZOV Y, TONCHEV T, DOBRICHOV I 2004 Handbook of forest measurements (in Bulgarian). Bulvark, Sofia, Bulgaria, $419 p$ 